\section{The Chengjiang Biota:}

Record of the Early

\section{Cambrian}

Diversification of Life and Clues to

\section{Exceptional}

\section{Preservation of Fossils}

Loren E. Babcock, Department of Geological Sciences, The Ohio State University,

Columbus, OH 43210, USA,

babcock.5@osu.edu

Wentang Zhang, Nanjing Institute of Geology and Palaeontology, Academia Sinica, Nanjing 210008, China

Stephen A. Leslie, Department of Earth Sciences, University of Arkansas at Little Rock, Little Rock, AR 72204, USA

ABSTRACT
The Chengjiang Biota, from Yunnan,
China, is the most diverse assemblage of
Early Cambrian marine fossils known. Just
like the celebrated Burgess Shale (Middle
Cambrian) of British Columbia, Canada,
Chengjiang preserves not only fossils having
hard skeletal parts (which is typical of most
sedimentary deposits), but it also preserves
in exquisite detail nonmineralized skeletal
parts and internal soft parts of organisms
(which is much more unusual in sedimentary
deposits). The Chengjiang deposit, and the
somewhat younger Burgess Shale, both
provide important guides to diversity and
evolutionary rates during the early
Phanerozoic diversification event known as
the Cambrian "explosion." The Chengiiang
Biota bridges a critical time between decline
of the Late Neoproterozoic (latest
Precambrian) Ediacaran biota and the
terminal Early Cambrian extinction, and
provides further evidence that the Cambrian
explosion is part of an evolutionary transition
that began in the Late Neoproterozoic. As we
seek to understand the circumstances
surrounding exceptional preservation
generally, not just during the Cambrian,
Chengjiang provides an important
perspective on depositional conditions.
Interpretation of the preservation of Burgess
Shale-type organisms has been long
dominated by the Burgess Shale model, in
which organisms were washed from an oxic
environment, where they were living, into an

anoxic environment, where they were quickly buried. Anoxia inhibited the destructive activity of biodegraders (scavengers, bacteria, and burrowers) and probably played a role in early diagenesis Other deposits of exceptional preservation indicate that biodegraders were limited long enough for the early stages of fossilization to occur under at least two other circumstances. First, immobile benthic creatures could be smothered in place by rapidly deposited mud, and then preserved through early diagenetic activity mediated by anoxic conditions developed within the sediment. Second, in Chengjiang muds, exceptional preservation is inferred to have occurred in a restricted-shelf, shallow sea. Here, as in some Carboniferous deposits, factors related to tidally influenced shelf conditions limited the activity of biodegraders, and high sedimentation rates provided for quick burial. With the addition of new models for exceptional preservation in the Cambrian, this phenomenon should be viewed less as a result of extraordinary, one-time-only, depositional conditions, and more the result of minor or short-lived perturbations in depositional circumstances common to epeiric seas. Similar perturbations led to exceptional preservation in similar environments, but at different times, during the Phanerozoic.

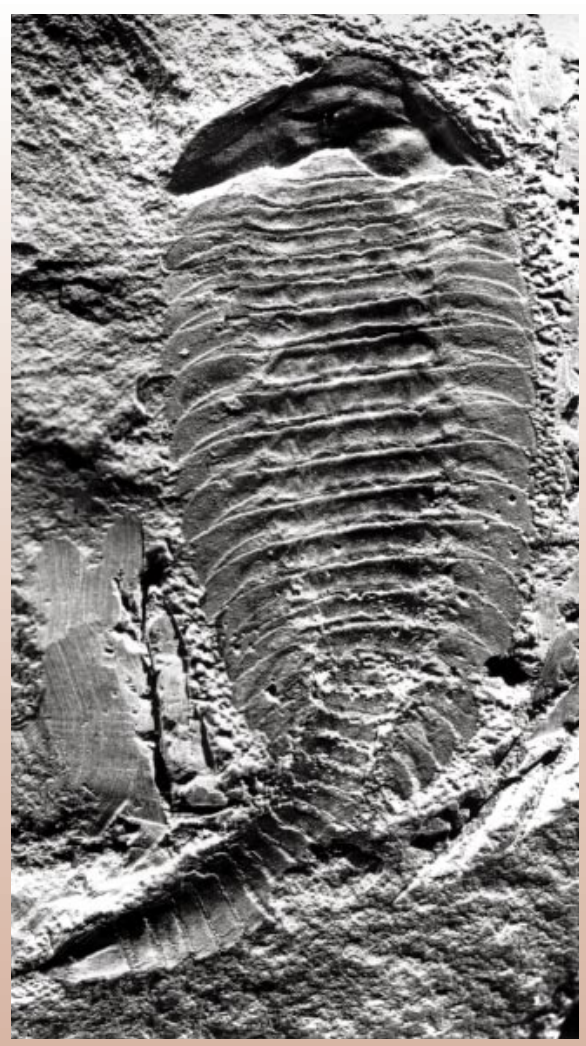

Figure 1. A primitive arthropod, Fuxianhuia protensa, which had a chitinous (nonmineralized) exoskeleton. This specimen, like all specimens illustrated here, is from Maotianshan, Yunnan, China. Length of specimen as preserved: $5.0 \mathrm{~cm}$

\section{INTRODUCTION}

$\checkmark$ he Neoproterozoic-Cambrian transition was a time of fundamental change in the history of life. Between the Late

Neoproterozoic (ca. $570 \mathrm{Ma}$ ) and the late Early Cambrian (ca. $510 \mathrm{Ma}$ ), representatives of most important, multicellular marine animals and plants had evolved sufficiently to leave a fossil record, and had undergone early experimentation with body plans and habitats. During the transition interval, predation had emerged as a significant factor in evolution (McMenamin, 1986; Babcock, 1993; Bengtson, 1994), and probably had a causal link, along with geochemical factors, to the appearance and later development of mineralized skeletons. By the Early

Cambrian, a transition from a microbial matdominated sediment-water interface to a more blurry, burrowed interface in shallowmarine settings was well under way (Seilacher and Pfluger, 1994; Bottjer et al., 2000). This time of rapid diversification among marine animals, experimentation with new body plans, and shifting ecological setting, is referred to as the Cambrian "explosion." In terms of macroscopic organisms, this rather protracted "event" is represented in the rock record by a transition (Bengtson, 1994; Grotzinger et al., 1995) from Neoproterozoic strata yielding nonmineralized Ediacaran-type organisms (Seilacher, 1989; Fedonkin, 1994; Narbonne, 1998), a few small, hard part-secreting organisms (Grant, 1990; Bengtson, 1994; Gehling and Rigby, 1996; Grotzinger et al., 2000), and a limited number of trace fossils (e.g., Corsetti and Hagadorn, 2000) to Lower Cambrian strata having an increasing array of fossils (Figs. 1, 2). Lowermost Cambrian strata (Nemakit-Daldynian to Tommotian stages) yield small, isolated plates (small shelly fossils, which are disarticulated multielement skeletons) and few trace fossils, but overlying strata of the Atdabanian and Botomian stages have more abundant and diverse fossils comprising shelly skeletons of invertebrates (mollusks, brachiopods, echinoderms, hyoliths, and reef-forming archaeocyathid sponges) and an increasing number of trace fossils (Fig. 2). In this interval, the rich fossil record of the Phanerozoic begins. By about $518 \mathrm{Ma}$, and in the midst of this dramatic biological change, siliciclastic muds in present-day Chengjiang County and surrounding areas of Yunnan Province, China (Figs. 3, 4), buried and preserved in great anatomical detail the remains of animals, plants, and macroscopic bacterial colonies that comprise the Chengjiang Biota (Figs. 1, 5, 6; Table 1).

Biological changes that occurred during the Neoproterozoic-Cambrian transition closely followed major physical and chemical changes of global scale. The Late Neoproterozoic witnessed the breakup of Rodinia, and collisional events that resulted in partial assembly of Gondwana (Hoffman, 1992; Unrug, 1997; Karlstrom et al., 1999). 


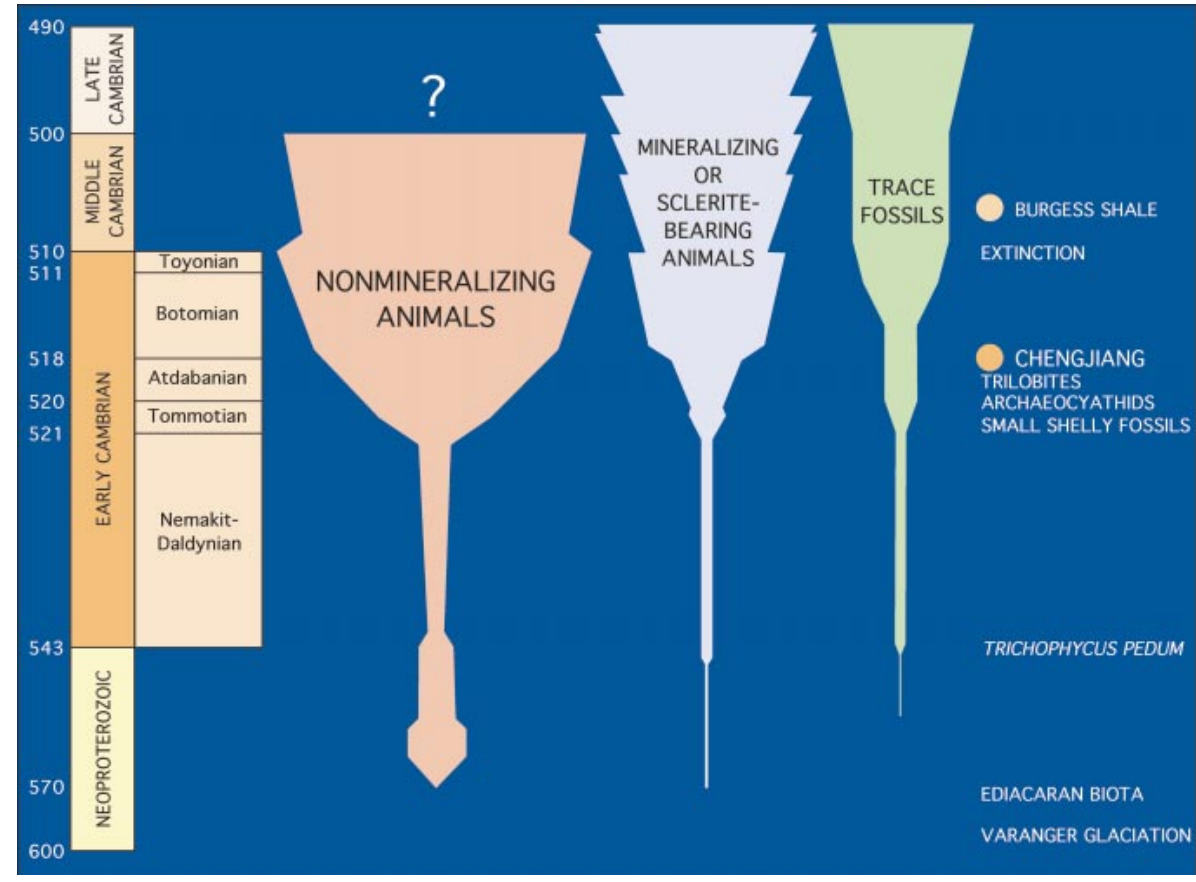

Figure 2. Generalized Late Neoproterozoic-Cambrian stratigraphy and biotic record showing the position of the Chengjiang Biota. Age estimates are extrapolated from Grotzinger et al. (1995), and Landing et al. (1998, 2000).

High spreading rates and high volumes of mid-ocean ridges fueled expansion of world oceans over many cratonic areas (Nicholas, 1996). Melting of the Varanger (Marinoan) glaciers (Knoll and Walter, 1992) also played a role in marine flooding of the continents. Flooding of the continents led to increased erosion rates (Montañez et al., 2000), and changes in ocean chemistry (Knoll and Walter, 1992; Nicholas, 1996; Montañez et al., 2000). Notably, increased oxygenation of the world ocean (Canfield and Teske, 1996) helped set the stage for the rise and later diversification of multicellular animals.

The Cambrian explosion is one of the most remarkable biological phenomena documented in the fossil record. Based on recent recalibration of the Cambrian time scale (Grotzinger et al., 1995; Bowring and Erwin, 1998; Landing et al., 1998, 2000), most of the development of skeletonized animals occurred during a relatively short interval of Early Cambrian time (Tommotian-Botomian; ca. 521-511 Ma; Fig. 2). The combination of major biological changes and propitious sedimentary conditions (Butterfield, 1995) has led to the preservation of an impressive, and rather detailed, record of the diversification event. At the end of the Early Cambrian, ca. $510 \mathrm{Ma}$, the major trilobite groups in Laurentia and Gondwana became extinct (Palmer, 1998). This, perhaps the first major extinction event of the Phanerozoic (Fig. 2), probably had some effect on animals lacking mineralized skeletons, but that effect has not been evaluated in detail. About 4 m.y. after the terminal Early Cambrian extinction, the well-known Burgess Shale (Fig. 2) of British Columbia, Canada (ca. 506 Ma) was deposited. The Burgess Shale provides an outstanding record of Middle Whittington, 1985; Briggs et al., 1994). Unlike most deposits, which contain only fossils with hard parts, the Burgess Shale contains many fossils retaining nonmineralized skeletal parts and internal soft parts. Because of this unusual preservation, we know significantly more about Cambrian life forms than we could possibly infer from the fossil record of hard parts alone. Were it not for the Burgess Shale and other Burgess Shale-type deposits, we would substantially underestimate the magnitude of the Cambrian explosion, because the record of shelly (or hard-part-bearing) fossils comprises only an estimated 3\%-20\% of the Cambrian biota (Conway Morris, 1986; Leslie et al., 1996).

Circumstances leading to exceptional preservation are not unique to the Burgess Shale. Such preservation is now known from about 40 Cambrian sites globally (e.g., Conway Morris, 1985; Allison and Briggs, 1991), although most of the sites yield few exceptionally preserved fossils. The quality of preservation in many of these deposits is high, but of them, only the Chengjiang deposit rivals the Burgess Shale in diversity of preserved species (approximately 170 species; e.g., Zhang and Hou, 1985; Zhang, 1987; Chen et al., 1997; Babcock and Chang, 1997; Chen and Zhou, 1997; Hou and Bergström, 1997; Hou et al., 1999; Shu et al. 1999). By the end of the Middle Cambrian (ca. $500 \mathrm{Ma}$ ), sedimentary, geochemical, and ecological conditions favoring the exceptional preservation of nonmineralized organisms in nonconcretionary strata declined (Butterfield, 1995). Marine sedimentary environments suitable for exceptional preservation reappeared during
Cambrian life forms (Conway Morris, 1985 other intervals of the Phanerozoic (for example, during the Late Silurian and Pennsylvanian), but ecological changes such as deeper and more extensive burrowing (Droser and Bottjer, 1988; Bottjer et al., 2000), evolving predator-prey interactions (Babcock, 1993; Pratt, 1998), and extinction of some forms and evolution of others, resulted in the appearance of new casts of characters in the younger deposits.

\section{PALEOECOLOGY AND PRESERVATION}

The Chengjiang Biota is the most diverse assemblage of Cambrian organisms from Gondwana, and its component species have evolutionary links to the Precambrian as well as to the post-Cambrian Phanerozoic. Fossils of the Chengjiang Biota include some that have a documented fossil record dating to the Ediacaran (Neoproterozoic) or earlier biotas of the Precambrian. Spiraled, twisted colonies of blue-green bacteria represent a prokaryotic lineage that evolved in the Archean. Probable green algae, brown algae, and sponges have evolutionary roots in the Proterozoic. The fine quality of preservation at Chengjiang allows some large, predatory animals to be linked with arthropods recognized from the Burgess Shale and elsewhere (Chen et al., 1994). Brachiopods (Fig. 6), sponges, and a variety of worms (Chen et al., 1997; Chen and Zhou, 1997; Fig. 5), share common ancestries with animals that played important ecological roles later in the Phanerozoic. Even early chordates are present in the Chengjiang Biota (Shu et al., 1999).

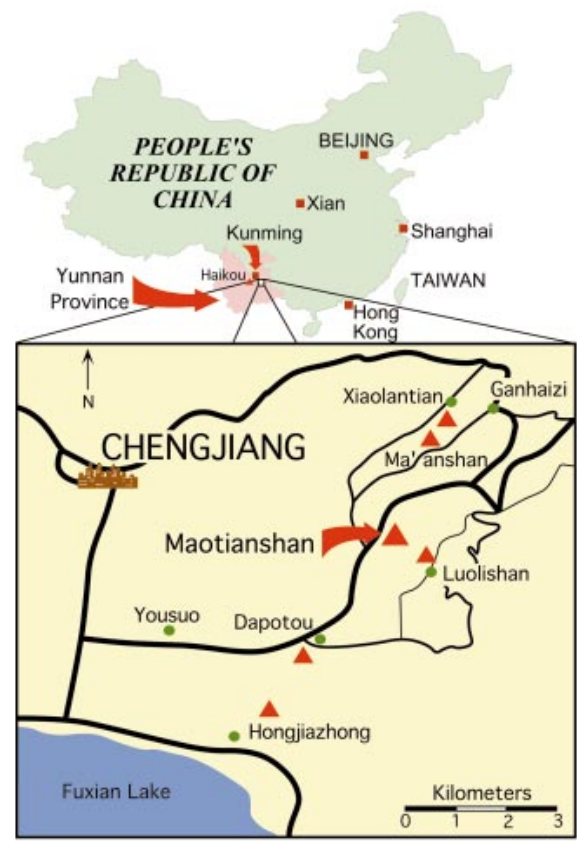

Figure 3. Map showing Maotianshan and other localities in Yunnan Province, China, yielding exceptionally preserved fossils of the Chengjiang Biota. Triangles represent some of the known localities, and show that examples of exceptional preservation are widely distributed. 


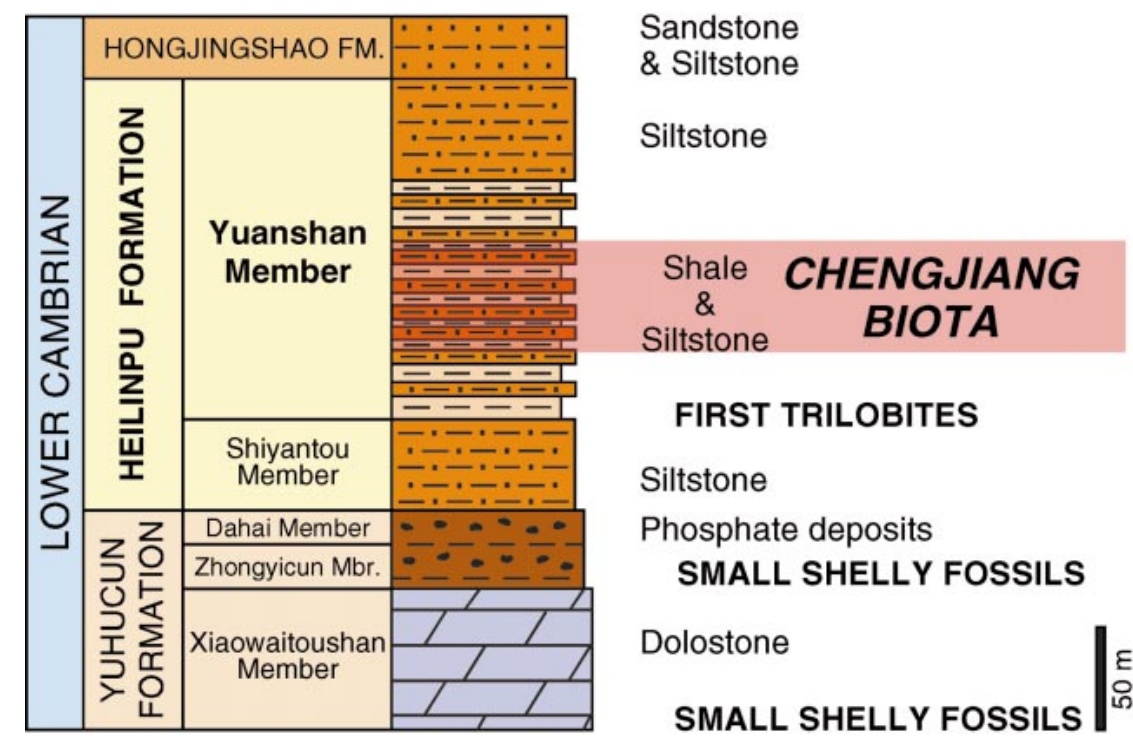

Figure 4. Generalized Lower Cambrian stratigraphy of Yunnan, China, showing the position of beds yielding exceptionally preserved fossils of the Chengjiang Biota, and the relationship of these fossils to some other important fossil occurrences.

The Chengjiang Biota provides a significant point of comparison for other major Burgess Shale-type sites, most of which are in Laurentia and most of which are younger in age. Approximately 15\% of genera and $85 \%$ of phylum-level groups from the Middle Cambrian Burgess Shale also are present in the Early Cambrian Chengjiang deposit. The only major groups present in the Burgess Shale but absent, or nearly so, from Chengjiang, are echinoderms and mollusks (Table 1). The reason for the nearabsence of these animals from Chengjiang is more likely the result of environmental conditions than true biogeographic

differences. Indeed, in other respects, there is a rather striking biogeographic similarity among Cambrian nonmineralizing organisms between Laurentian biotas (including that of the Burgess Shale) and Gondwanan biotas (including that of Chengjiang). Representatives of the Burgess Shale-type organisms were clearly widespread during the Early and Middle Cambrian, and also persistent during that interval of time (Conway Morris, 1985).

Approximately $65 \%$ of all macroscopic fossils from Chengjiang and more than 50\% of the described species are arthropods (Fig. 1). Numerically, arthropods (trilobites, crustaceans, etc.) had become the dominant animals on Earth near the beginning of the Phanerozoic, and they have remained in that position ever since. In the modern world, however, terrestrial insects, which were not present during the Cambrian, outnumber all other animals combined. Among arthropods, the most abundant forms are small bivalved forms (called bradoriids) having variably pliable exoskeletons. Few of the Chengiiang arthropods developed hard, mineralreinforced exoskeletons of the type known from trilobites and some of the postCambrian crustaceans (e.g., ostracodes, crabs, and lobsters). Instead, most Early
Cambrian arthropods had relatively pliable, nonmineralized exoskeletons that more closely resembled those of modern insects.

Overall, census information indicates that more than $97 \%$ of Chengjiang organisms lacked hard skeletal parts (Leslie et al., 1996). That is to say, fewer than 3\% of the organisms known from the Chengjiang deposit are present in contemporaneous strata that contain only shelly fossils. The most common of the shelly fossils in Chengjiang are trilobites (Zhang, 1987), but they comprise fewer than $5 \%$ of the total number of animal fossils.

Nearly all of the Chengjiang animals were bottom dwellers, and show evidence of short-distance transportation following death. Some, such as sponges, were filter feeders that in life were partly buried in sediment. Sponges, however, are characteristically preserved flat and often current-aligned along bedding planes, indicating that they were uprooted prior to burial. Burrowing organisms such as some of the worms, which had a range of feeding styles, are rarely preserved in their burrows; rather, they too are laid out along bedding planes (Fig. 5). Arthropods were mobile and had diverse feeding habits ranging from carnivory and scavenging through herbivory, filter feeding, and sediment deposit feeding. Predator-prey interactions are represented by anomalocaridid arthropods and trilobites showing healed bite marks. Occasionally, clusters of fossils are arranged as if in coprolites (e.g., Hou et al., 1999). These clusters often contain small bradoriid arthropods, which probably lived in large swarms (similar to modern krill) along Gondwanan shelf areas, and served as a major food source for certain predators. Mollusks and undoubted echinoderms are rare in Chengjiang, perhaps because the restricted shelf setting of Chengjiang lacked a consistent, normal-marine-salinity environment that many Cambrian species of the groups required

Chengjiang organisms were mostly buried and preserved in thin-bedded muds, but rarely immobile benthic organisms were rapidly smothered under a layer of silt or fine sand. These sediment-smothering beds (or "obrution beds"; Seilacher et al., 1985) are comparable to deposits that buried articulated echinoderms and other animals in the Cambrian of Laurentia (e.g., Robison, 1991; Liddell et al., 1997), and in other intervals of the Paleozoic (e.g., Taylor and Brett, 1996). Sediment smothering, along with stabilization of sediment surfaces by microbial mats, was also important in preserving Ediacaran-type organisms during the Neoproterozoic (Seilacher, 1989; Seilacher and Pfluger, 1994; Gehling, 1999).

\section{DEPOSITIONAL SETTING}

The Chengjiang deposit provides a new perspective on the processes leading to exceptional preservation in the Cambrian, as explained in the following section. To understand the significance of this perspective, it is important to contrast the depositional settings of the Burgess Shale and Chengjiang. The well-documented depositional scenario of the Burgess Shale (e.g., Whittington, 1985; Briggs et al., 1994) involved an oxic environment teeming with life near the base of a carbonate reef that rimmed the Cordilleran margin of Laurentia Occasionally, slope instability resulted in rapid downslope movement of mud and organisms in debris flows. Organisms were transported into anoxic waters and buried in oxygen-deficient muds. Decay and scavenging was inhibited by anoxia, and early fossilization occurred (Allison, 1988; Allison and Briggs, 1991).

The Chengjiang Biota, which occurs in the Yuanshan Member of the Heilinpu Formation (Fig. 4), includes life forms that inhabited the Southwest China Platform, one of several Gondwanan terranes. Regional studies

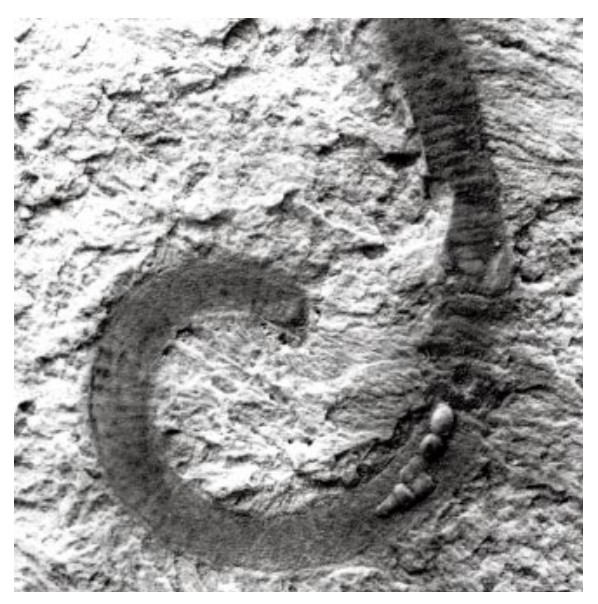

Figure 5. A worm, Maotianshania cylindrica, showing remains of an incompletely digested meal in the gut tract. Length of specimen as preserved: $1.4 \mathrm{~cm}$. 


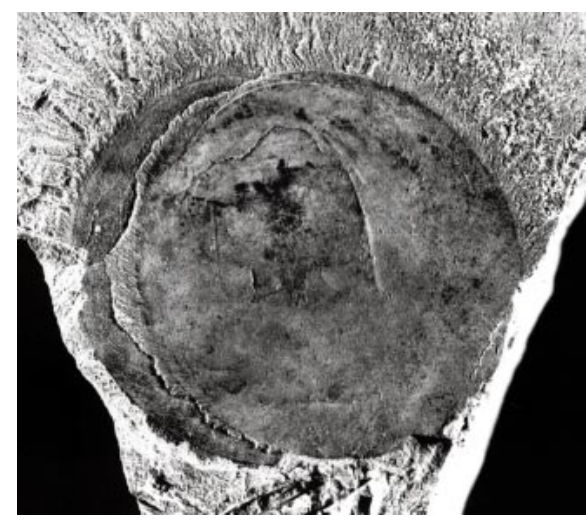

Figure 6. A brachiopod, Heliomedusa orienta. The two valves have separated slightly, and around the margins of the valves, fine, threadlike mantle setae (part of the soft anatomy) are evident. Length of specimen: $1.7 \mathrm{~cm}$.

indicate that deposition of Heilinpu Formation sediments took place in relatively shallow, tropical, shelf seas, and above storm wave base in a somewhat restricted basin during a late transgressive to highstand phase of coastal onlap. Exceptionally preserved fossils in the Yuanshan Member usually occur within rhythmically thin-bedded successions of gray-green to yellow shales. Light-dark couplets of millimeter-scale bedding show a periodicity suggesting tidally influenced deposition (Fig. 7), which in places is comparable to tidal rhythmicity inferred from the Carboniferous (e.g. Feldman et al., 1993)

Burial and fossilization of Chengjiang organisms under thin sheets of sediment occurred during times when areas of the subtidal shelf were stressed, which limited the biota that depended on conditions of normal marine salinity. During times when shelf environments were normal, most non shelly Chengjiang-type organisms would have undergone rapid breakdown through scavenging and microbial decay. Although shallow burrowing occurred in some intervals of the Yuanshan Member, indicating that conditions fluctuated between tolerable and intolerable for living organisms, beds yielding exceptionally preserved fossils are rarely burrowed.

In Chengiiang, inferred proximity to an ancient coastline, and evidence pointing to tidal pumping and occasional fresh water influxes to the shelf evidently played important roles in exceptional preservation. Nonmineralizing organisms were preserved over a wide geographic area of what is now eastern Yunnan Province (Fig. 3). At present, we can only infer what set of factors was proximally responsible for restriction of scavenging activity and retardation of bacterial decay. In the nearshore, restricted shelf area, however, salinity could have fluctuated at times between normal marine and brackish (or perhaps even fresh?) water, and therefore may have played a significant role in the process of exceptional preservation. Salinity was inferred to have played a similar role in exceptional preservation in some Carboniferous and Permian deposits (Babcock et al., 2000). Laboratory experiments involving the exposure of dead marine organisms to fresh water conditions show that the decay process is significantly lengthened (Babcock, 1998) because the activity of microbial biodegraders is inhibited. By implication, the occasional influx of fresh or brackish water to the Southwest China shelf during the Early Cambrian might have slowed the decay process long enough for burial, possible exposure to anoxic conditions below the sediment-water interface, and early diagenesis of organic remains to occur Furthermore, salinity fluctuation would have, at times, limited the presence of burrowers, resulting in the preservation of thinly laminated muds. Noteworthy is the near exclusion of stenohaline echinoderms and mollusks from the Chengjiang Biota, as it suggests a lack of constant normal marine conditions in this setting.

\section{DEPOSITIONAL MODELS FOR BURGESS SHALE-TYPE DEPOSITS}

Combined evidence from Chengjiang, China, and western North America indicates that Burgess Shale-type preservation in nonconcretionary Lower and Middle Cambrian strata developed under at least three conditions (Fig. 8). The conditions were not necessarily mutually exclusive. Deposition of the Burgess Shale involved rapid downslope transportation of live and recently dead organisms from an oxic marine environment into an adjacent anoxic environment (e.g., Whittington, 1985; Briggs et al., 1994; Fletcher and Collins, 1998). Here, we refer to this as the anoxic model of exceptional preservation (Fig. 8). The relationship between an anoxic environment and exceptional preservation has been well documented for the Burgess Shale (e.g. Whittington, 1985; Briggs et al., 1994; Fletcher and Collins, 1998); that model seems to explain the occurrence of some, but not all, Cambrian deposits of exceptional preservation. Preservation of nonmineralized organisms is also associated with anoxic environments in a number of other Phanerozoic deposits, notably Pennsylvanian black shales of the United States (Zangerl and Richardson, 1963). Many Cambrian occurrences of exceptional preservation, however, do not seem to be associated with anoxic environments and black shale deposition, although after burial, oxygen deficiency within the sediment may have mediated the fossilization process. At least two other circumstances of exceptional preservation seem to have operated in the Cambrian, and both have analogs in the post-Cambrian. Deposition of the shales in which most Chengjiang organisms were preserved is referred to as the tidal model of exceptional preservation (Fig. 8). Tidal fluctuation across broad shelf areas during the Cambrian are inferred to have generated fluctuations in salinity that occasionally reached levels inimical to scavengers and other marine biodegraders. An analogous mechanism may be responsible in part for exceptional preservation associated with various tidally influenced, marginal-marine, or shelf environments of the Carboniferous (e.g., Baird et al., 1985; Feldman et al., 1993; Maples and Schultze, 1988). Lastly, sediment smothering, or the obrution model, constitutes the third major process leading to exceptional preservation in the Early and Middle Cambrian (Fig. 8). Sediment smothering of live, benthic animals has led to the preservation of remarkably dense associations of articulated echinoderms, sponges, trilobites, and other fossils most notably in the Cambrian (Robison, 1991; Liddell et al., 1997), Silurian (e.g., Taylor and Brett, 1996), and Devonian (e.g., Bartels et al., 1998).

Exceptional preservation in the Cambrian seems to have occurred under at least three circumstances, all of which are known from other intervals of the Phanerozoic, and which are the result of minor environmental perturbations (crossing an oxygen or salinity threshold, or rapid influx of sediment) that

TABLE 1. COMPARISON OF MAJOR FOSSIL GROUPS REPRESENTED IN THE BURGESS SHALE BIOTA OF BRITISH COLUMBIA AND IN THE CHENGJIANG BIOTA OF YUNNAN, CHINA

\begin{tabular}{|c|c|c|}
\hline \multicolumn{2}{|c|}{ Burgess Shale } & Chengjiang \\
\hline $\begin{array}{l}\text { Blue-green } \\
\text { bacteria }\end{array}$ & $x$ & $x$ \\
\hline Algae & $X$ & $x$ \\
\hline Sponges & $x$ & $x$ \\
\hline Cnidarians & $x$ & $x$ \\
\hline Ctenophores & $x$ & $x$ \\
\hline Brachiopods & $X$ & X \\
\hline Mollusks & $x$ & absent \\
\hline Hyoliths & $x$ & X \\
\hline Priapulid worms & $x$ & $X$ \\
\hline Annelid worms & $x$ & $x$ \\
\hline Lobopods & $x$ & $x$ \\
\hline Arthropods & $x$ & $X$ \\
\hline Echinoderms & $x$ & absent \\
\hline Hemichordates & $X$ & $x$ \\
\hline Chordates & $x$ & $x$ \\
\hline
\end{tabular}

Note: The Burgess Shale list is compiled from Whittington (1985) and Briggs et al. (1994). The Chengjiang list is compiled from a voluminous literature reflecting the work of numerous scientists. Because of space limitations, only a few citations (Zhang and Hou, 1985; Zhang, 1987; Chen et al., 1994, 1997; Babcock and Chang, 1997; Chen and Zhou, 1997; Hou and Bergström, 1997; Hou et al., 1999; Shu et al., 1999) are provided in the reference list; the reader is referred to these papers for a more complete perspective of the literature. Presence of a group in each biota is indicated by an $\mathrm{X}$ 


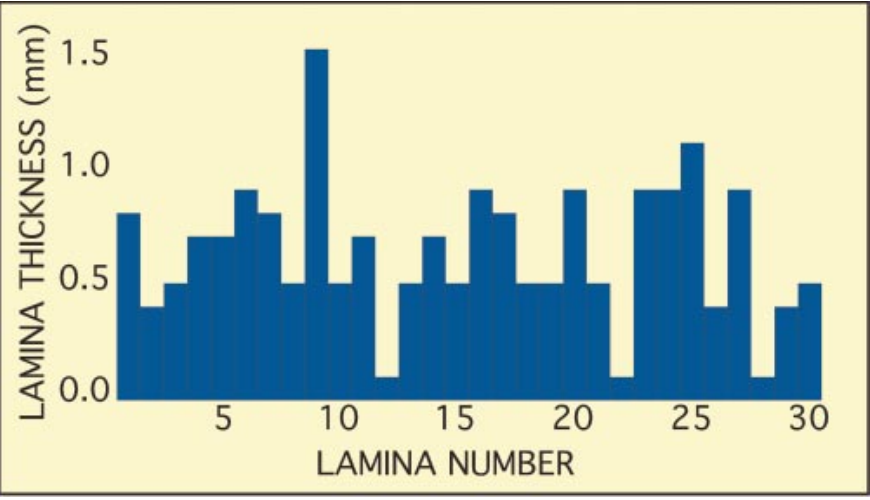

Figure 7. Bar graph showing thicknesses of mud laminae through an interval of the Chengjiang deposit that bears exceptionally preserved fossils (Heilinpu Formation, Yuanshan Member at Maotianshan, China). The laminae show a periodicity resembling that reported in some tidally influenced deposits of exceptional preservation in the Carboniferous (e.g., Feldman et al., 1993, and references therein).

must have been relatively common in epeiric seas. In a sense, then, the phenomenon of exceptional preservation could be viewed as a much more ordinary occurrence, taking place whenever and wherever biodegraders were limited from an area subject to episodic sedimentation. This new perspective on Cambrian deposits of exceptional preservation helps to explain the widespread occurrence of Burgess Shale-type deposits (Conway Morris, 1985), and provides some indication that the best-described biotas (particularly the Burgess Shale and Chengiiang biotas) represent a fair and proportional sampling of Cambrian life forms.

\section{ACKNOWLEDGMENTS}

Discussions with many colleagues, including J. Bergström, C. E. Brett, D.E.G. Briggs, G.E. Budd, J.Y. Chen, D.H. Collins, B.-D. Erdtmann, R.J. Malcuit, C.G. Maples, S. Conway Morris, X.G. Hou, S.X. Hu, Z.W. Jiang, A.R. Palmer, J.S. Peel, H.L. Luo, J.M. St. John, R.A. Robison, A. Seilacher, M. Steiner, W.G. Sun, W.L. Taylor, and L.W. Xiang, have been helpful in the preparation of this paper. Helpful reviews were provided by D.E. Elliot, C.G. Maples, and S. Conway Morris; the editorial work of M.F. Miller is gratefully acknowledged. Grants from the National Science Foundation (EAR 9405990 and 0073089) to Babcock, and from the China National Natural Science Foundation to Zhang, supported this work.

\section{REFERENCES CITED}

Allison, P.A., 1988, Konservat-Lagerstätten: Cause and classification: Paleobiology, v. 14, p. 331-344.

Allison, P.A., and Briggs, D.E.G., 1991, Taphonomy of nonmineralized tissues, in Allison, P.A., and Briggs, D.E.C. eds., Taphonomy: Releasing the data locked in the fossil record: New York, Plenum Press, p. 26-70.

Babcock, L.E., 1993, Trilobite malformations and the fossil record of behavioral asymmetry: Journal of Paleontology, v. 67, p. $217-229$

Babcock, L.E., 1998, Experimental investigation of the processes of fossilization: Journal of Geoscience Education, v. 46, p. $252-260$

Babcock, L.E., and Chang [Zhang], W.T., 1997, Comparative taphonomy of two nonmineralized

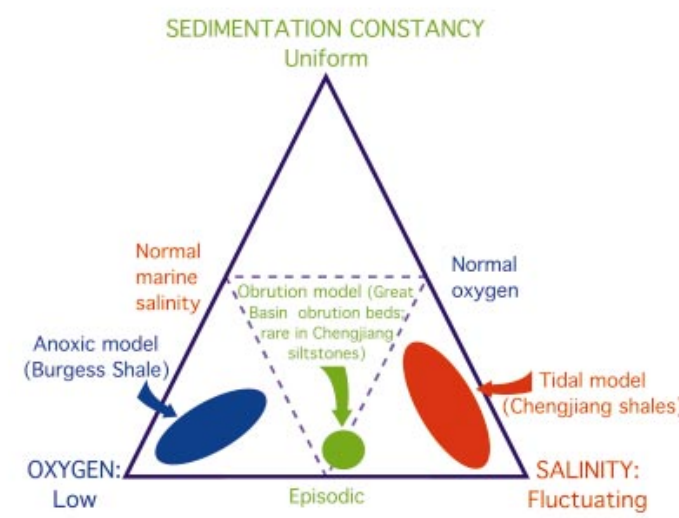

Figure 8. Triangular diagram showing major controls on exceptional fossil preservation in the Early and Middle Cambrian. Example deposits are indicated. arthropods, Naraoia (Nektaspida; Early Cambrian, Chengjiang Biota, China) and Limulus (Xiphosurida; Holocene, Atlantic Ocean): National Museum of Natural Science Bulletin, v. 10, p. 233-250.

Babcock, L.E., Merriam, D.H., and West, R.R., 2000, Paleolimulus, an early limuline (Xiphosurida), from Pennsylvanian-Permian Lagerstätten of Kansas and taphonomic comparison with modern Limulus: Lethaia, vol. 33, p. 129-141.

Baird, G.C., Shabica, C.W., Anderson, J.L., and Richardson, E.S., Jr., 1985, Biota of a Pennsylvanian muddy coast: Habitats within the Mazonian delta complex, northern Illinois: Journal of Paleontology, v. 59, p. 253-281.

Bartels, C., Briggs, D.E.G., and Brassel, G., 1998, The fossils of the Hunsrück Slate: Marine life in the Devonian: Cambridge, Cambridge University Press, 309 p.

Bengtson, S., 1994, The advent of animal skeletons, in Bengtson, S., ed., Early life on Earth: New York, Columbia University Press, p. 412-425.

Bottjer, D.J., Hagadorn, J.W., and Dornbos, S.Q., 2000, The Cambrian substrate revolution: GSA Today, v. 10, no. 9 , p. 1-7.

Bowring, S.A., and Erwin, D.H., 1998, A new look at evolutionary rates in deep time: Uniting paleontology and high-precision geochronology: GSA Today, v. 8, no. 9 , p. 1-8.

Briggs, D.E.G., Erwin, D.H., and Collier, F.J., 1994, The fossils of the Burgess Shale: Washington, Smithsonian Institution Press, 238 p.

Butterfield, N.J., 1995, Secular distribution of Burgess Shale-type preservation: Lethaia, v. 28, p. 1-13.

Canfield, D.E., and Teske, A., 1996, Late Proterozoic rise in atmospheric oxygen concentration inferred from phylogenetic and sulphur-isotope studies: Nature, v. 382, p. 127-132.

Chen, J.Y., Ramsköld, L., and Zhou, G.Q., 1994, Evidence for monophyly and arthropod affinity of giant Cambrian predators: Science, v. 264, p. 1304-1308.

Chen, J.Y., and Zhou, M.Y., 1997, Biology of the Chengjiang fauna: National Museum of Natural History Bulletin, v. 10, p. 11-105.

Chen, J.Y., Zhou, G.Q., Zhu, M.Y., and Yeh, K.Y., 1997, The Chengjiang Biota: A unique window of the Cambrian explosion: National Museum of Natural Science: Taichung, Taiwan, $222 \mathrm{p}$

Conway Morris, S., 1985, Cambrian Lagerstätten: Their distribution and significance: Philosophical Transactions of the Royal Society of London, v. B 311, p. 48-65.

Conway Morris, S., 1986, The community structure of the Middle Cambrian phyllopod bed (Burgess Shale): Palaeontology, v. 29, p. 423-467.

Corsetti, F.A., and Hagadorn, J.W., 2000. PrecambrianCambrian transition: Death Valley, United States: Geology, v. 8 , p. 299-302.
Droser, M.L., and Bottjer, D.J., 1988, Trends in depth and extent of bioturbation in Cambrian carbonate marine environments, western United States: Geology, v. 16, p. 233-236.

Fedonkin, M.A., 1994, Early multicellular fossils, in Bengtson, S., ed., Early life on Earth: New York, Columbia University Press, p. 370-388.

Feldman, H.R., Archer, A.W., Kvale, E.P., Cunningham, C.R., Maples, C.G., and West, R.R., 1993, A tidal model of Carboniferous Konservat-Lagerstätten formation: Palaios, v. 8, p. 485-498.

Fletcher, T.P., and Collins, D.H., 1998, The Middle Cambrian Burgess Shale and its relationship to the Stephen Formation in the southern Canadian Rocky Mountains: Canadian Journal of Earth Sciences, v. 35, p. 413-436.

Gehling, J.G., 1999, Microbial mats in terminal Proterozoic siliciclastics: Ediacaran death masks: Palaios, v. 14, p. 40-57.

Gehling, J.G., and Rigby, J.K., 1996, Long expected sponges from the Neoproterozoic Ediacaran fauna of South Australia: Journal of Paleontology, v. 70, p. 185-195. Grant, S.W.F., 1990, Shell structure and distribution of Cloudina, a potential index fossil for the terminal Proterozoic: American Journal of Science, v. 290-A p. 261-294.

Grotzinger, J.P., Bowring, S.A., Saylor, B.Z., and Kaufman, A.J., 1995, Biostratigraphic and geochronologic constraints on early animal evolution: Science, v. 270, p. 598-604.

Grotzinger, J.P., Watters, W.A., and Knoll, A.H., 2000 Calcified metazoans in thrombolite-strombolite reefs of the terminal Proterozoic Nama Group, Namibia. Paleobiology, v. 26, p. 334-359.

Hoffman, P.F., 1992, Did the breakout of Laurentia turn Gondwanaland inside out?: Science, v. 252, p. 1409-1412.

Hou, X.G., and Bergström, J., 1997, Arthropods of the Lower Cambrian Chengjiang fauna, Southwest China: Fossils and Strata, no. 45, $116 \mathrm{p}$.

Hou, X.G., Bergström, J., Wang, H.F., Feng, X.H., Chen, A.L., 1999, The Chengjiang fauna: Exceptionally wellpreserved animals from 530 million years ago: Kunming, Yunnan Science and Technology Press, $170 \mathrm{p}$.

Karlstrom, K.E., Williams, M.L., McLelland, J., Geissman, J.W., and Åhäll, K.-I., 1999, Redefining Rodinia: Geologic evidence for the Australia-western U.S. connection in the Proterozoic: GSA Today, v. 9, no. 10, p. 1-7.

Knoll, A.H and Walter, M, 1992, Latest Proterozoic stratigraphy and Earth history: Nature, v. 356, p. 673-678. Landing, E., Bowring, S.A., Davidek, K.L., Westrop, S.R., Geyer, G., and Heldmaier, W., 1998, Duration of the Early Cambrian: U-Pb ages of volcanic ashes from Avalon and Gondwana: Canadian Journal of Earth Sciences, v. 35, p. 329-338.

Landing, E., Bowring, S.A., Davidek, K.L., Rushton, A.W.A., Fortey, R.A., and Wimbledon, W.A.P., 2000, Cambrian- 
Ordovician boundary age and duration of the lowest Ordovician Tremadoc Series based on U-Pb zircon dates from Avalonian Wales: Geological Magazine, vol. 137, p. 485-494.

Leslie, S.A., Babcock, L.E., and Zhang, W.T., 1996, Community composition and taphonomic overprint of the Chengiiang Bioty (Early Cambrian, China): Sixth North American Palo Conty Cam Publication 8, p. 237

Liddell, W.D., Wright, S.H., and Brett, C.E., 1997, Sequence stratigraphy and paleoecology of the Middle Cambrian Spence Shale in northern Utah and southern Idaho: Brigham Young University Geology Studies, v. 42, p. 59-78.

McMenamin, M.A.S., 1986, The garden of Ediacara: Palaios, v. 1 , p. $178-182$

Maples, C.G., and Schultze, H.-P., 1988, Preliminary comparison of the Pennsylvanian assemblage of Hamilton, Kansas, with marine and nonmarine contemporaneous assemblages: Kansas Geological Survey Guidebook Series, no. 6, p. 253-273.

Montañez, I.P., Osleger, D.A., Banner, J.L., Mack, L.E., and Musgrove, M., 2000, Evolution of the $\mathrm{Sr}$ and C isotope composition of Cambrian oceans: GSA Today, v. 10, no. 5 , p. 1-7.

Narbonne, G.M., 1998, The Ediacara biota: A terminal Neoproterozoic experiment in the evolution of life: GSA Today, v. 8 , no. 2, p. 1-6.

Nicholas, C.J., 1996, The Sr isotopic evolution of the oceans during the "Cambrian explosion": Geological Society [London] Journal, v. 153, p. 243-254.

Palmer, A.R., 1998, Terminal Early Cambrian extinction of the Olenellina: documentation from the Pioche Formation, Nevada: Journal of Paleontology, v. 72, p. 650-672.

Pratt, B.R., 1998, Probable predation on Upper Cambrian trilobites and its relevance for the extinction of soft-bodied Burgess Shale-type animals: Lethaia, v. 31, p. 73-88.

Robison, R.A., 1991, Middle Cambrian biotic diversity: Examples from four Utah Lagerstätten, in Simonetta, A.M., and Conway Morris, S., eds., The early evolution of Metazoa and the significance of problematic taxa: Cambridge, Cambridge University Press, p. 77-98.

Seilacher, A., 1989, Vendozoa: Organismic construction in the Proterozoic biosphere: Lethaia, v. 22, p. 229-239.

Seilacher, A., and Pfluger, F., 1994, From biomats to benthic agriculture: A biohistoric revolution, in Krumbein, W.S., et al., eds., Biostabilization of sediments: Oldenberg, Germany, Bibliotheks und Informationsystem der Universität Oldenberg p. 97-105.

Seilacher, A., Reif, W.-E., and Westphal, F., 1985,

Sedimentological, ecological, and temporal patterns of fossilLagerstätten: Philosophical Transactions of the Royal Society of London, v. B 311, p. 5-24

Shu, D.G., Luo, H.L., Conway Morris, S., Zhang, X.L., Hu, S.X., Chen, L., Han, J., Zhu, M., Li, Y., and Chen, L.Z., 1999, Lower Cambrian vertebrates from South China: Nature, v. 402, p. $42-46$.

Taylor, W.L., and Brett, C.E., 1996, Taphonomy and paleoecol.og a (Wenlockian) Rochester Shale: Palaios, v. 11, p. 118-140.

Unrug, R., 1997, Rodinia to Gondwana: The geodynamic map of Gondwana supercontinent assembly: GSA Today, v. 7, no : 1, 1

Whittington, H.B., 1985, The Burgess Shale: New Haven Connecticut, Yale University Press, 151 p.

Zangerl, R., and Richardson, E.S., Jr., 1963, The paleoecologica history of two Pennsylvanian black shales: Fieldiana: Geology Memoirs, v. 4, p. 1-352.

Zhang W.T. 1987, Early Cambrian Chengjiang fauna and its trilobites: Acta Palaeontologica Sinica, v. 26, p. 223-236. Zhang, W.T., and Hou, X.G., 1985, Preliminary notes on the occurrence of the unusual trilobite Naraoia in Asia: Acta Palaeontologica Sinica, v. 24, p. 591-595.

Manuscript received October 1, 2000; accepted December 12, 2000.

\section{DIALOGULE}

\section{GSA Global Meeting Series Launched}

Ian Dalziel, GSA International Secretary

Home base for GSA is, of course, the continent of North America. Members and Fellows of the Society from the United States, Canada, and Mexico have, over the years, studied not only their own huge and diverse land mass and its submerged margins, but other continents, the ocean basins, and even the Moon and planets other than Earth, as well as processes that are well expressed worldwide. Recent advances in interdisciplinary Earth and space science emphasize the need to adopt a global perspective in many areas of study and demand that an intellectually healthy Society looks increasingly outward from North America.

GSA's Council has made this approach a high priority in strategic planning, but without abandoning GSA's traditional roots. The Global Review Board has been established to oversee initiatives in this area and will work with the International Secretary in fostering closer relationships with the scientific societies and scientists of other countries. Both will interact closely with the International Division.

Two possibilities currently under review are exchange programs for the support of young scientists to attend foreign meetings and reciprocal memberships with overseas societies. Establishment of a series of overseas, global meetings has already been approved.

In launching a series of global meetings, to be held every two years with the goal of fostering its globalization, GSA does not intend merely to organize meetings at various locations around the world. Geology is a field-based science, even in the era of global satellite data sets. Cooperation with scientists from other continents with their unique knowledge and different perspectives on the earth system is vital. Rather, the Society will cooperate closely with sister societies in other countries to cosponsor these meetings. Each meeting will focus on a specific topic appropriate for the location and matching the mutual interests of the sponsoring societies' membership.

At the first meeting, to be held in Edinburgh, Scotland, June 24-28, 2001, GSA and the Geological Society of London, two of the oldest and largest organizations of earth scientists in the world, jointly present Earth System Processes, a meeting to discuss the emerging global approach to the study of the planet that demands the interaction of traditional geologists with all the other sciences. Both major themes critical to understanding how our planet works will be considered at the meeting: Earth System Linkages, exploring the relationships between the solid Earth, hydrosphere, atmosphere, cryosphere, and biosphere; and Earth System Evolution, examining the way in which processes controlling the nature of the planet have changed since the birth of the solar system 4.5 billion years ago.

Future meetings in the series are being considered in Australia, South Africa, and South America. These and other meetings will address distinctive topics appropriate to the venue. Be a part of this exciting initiative from the start by coming to Edinburgh.

Details of the 2001 Earth Systems Processes meeting were announced in the second circular (see the November 2000 issue of GSA Today or visit www.geosociety. $\mathrm{org} /$ meetings/edinburgh/index.htm). Join us for a stimulating, interdisciplinary discussion in the unique setting where modern geology began with the publication of James Hutton's Theory of the Earth in 1788. The deadline for submitting abstracts is February 28, 2001, and for registration is April 30, 2001.

Site of the global meeting Earth Systems Processes, June 24-28, 2001, Edinburgh, Scotland, is a city where medieval buildings share the pavements with striking modern structures built on ice-sculptured volcanic landforms. Join your colleagues in this magnificent city with close ties to the history of earth science for what promises to be a memorable and significant gathering.

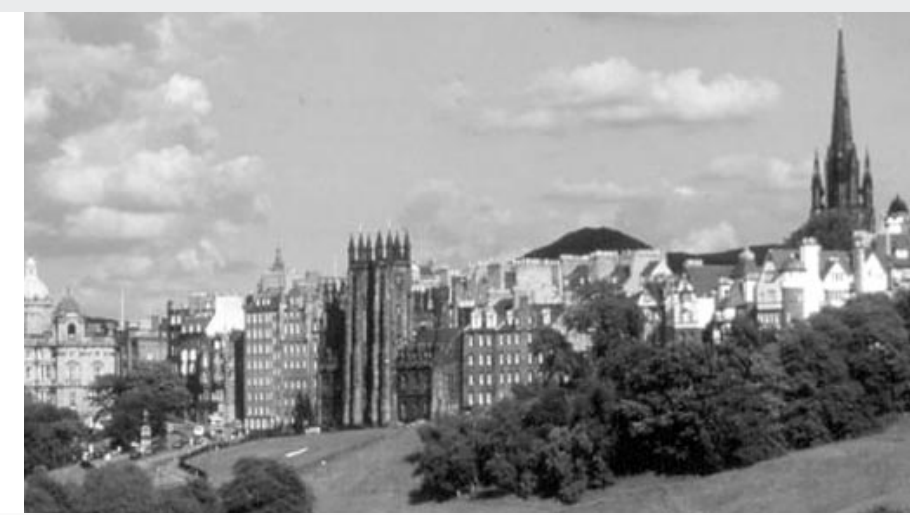

